\title{
AKTIVITAS ANTIMIKROBA EKSTRAK DAN FRAKSI ALGA ( Halimeda opuntia ) TERHADAP Escherichia coli, Staphylococcus aureus dan Candida albicans
}

\author{
Shinta Jolanda ${ }^{1)}$, Defny S. Wewengkang ${ }^{1)}$, Imam Jayanto ${ }^{1)}$ \\ 1) Program Studi Farmasi FMIPA UNSRAT Manado, 95115
}

\begin{abstract}
Algae Halimeda opuntia is one of the green algae type that contains bioactive compounds which can be used for the treatment of various diseases. This study aimed to determine the antimicrobial activity of extracts and fractions of algae Halimeda opuntia obtained from the Lembeh Bitung Strait against Escherichia coli, Staphylococcus aureus and Candida albicans. The samples were extracted by maceration using ethanol solvent and fractionation using methanol, chloroform, and n-hexane solvents. Antimicrobial activity was carried out by the agar diffusion method of paper discs. The results showed that ethanol extract was able to inhibit the growth of Staphylococcus aureus and Escherichia coli bacteria in the medium inhibitory category. While the methanol and chloroform fractions were only able to inhibit the growth of Staphylococcus aureus bacteria. The extract and all fractions did not show activity inhibiting the growth of Candida albicans fungi.
\end{abstract}

Keywords: Algae, Halimeda opuntia, antimicrobial activity, Escherichia coli, Staphylococcus aureus, Candida albicans

\begin{abstract}
ABSTRAK
Alga Halimeda opuntia merupakan salah satu jenis alga hijau yang memiliki kandungan senyawa bioaktif yang dapat digunakan untuk pengobatan berbagai penyakit. Penelitian ini bertujuan untuk mengetahui adanya aktivitas antimikroba dari ekstrak dan fraksi alga Halimeda opuntia yang diperoleh dari Selat Lembeh Bitung terhadap Escherichia coli, Staphylococcus aureus dan Candida albicans. Sampel diekstraksi dengan metode maserasi menggunakan pelarut etanol dan fraksinasi menggunakan pelarut metanol, kloroform, dan n-heksan. Aktivitas antimikroba dilakukan dengan metode difusi agar cakram kertas. Hasil penelitian menunjukkan bahwa ekstrak etanol, mampu menghambat pertumbuhan bakteri Staphylococcus aureus dan Escherichia coli dengan kategori daya hambat sedang. Sedangkan fraksi metanol dan fraksi kloroform hanya mampu menghambat pertumbuhan bakteri Staphylococcus aureus. Ekstrak dan semua fraksi tidak menunjukkan aktivitas menghambat pertumbuhan jamur Candida albicans.
\end{abstract}

Kata kunci: Alga, Halimeda opuntia, aktivitas antimikroba, Escherichia coli, Staphylococcus aureus, Candida albicans 


\section{PENDAHULUAN}

Indonesia sebagai negara yang kaya dengan keanekaragaman hayati memiliki berbagai macam tanaman laut yang dapat dimanfaatkan sebagai obat alternatif. Berbagai penelitian menunjukkan bahwa biota laut memiliki potensi yang sangat besar dalam menghasilkan senyawasenyawa aktif yang dapat digunakan sebagai bahan baku obat. Sejak tahun 1980-an, perhatian dunia pengobatan mulai terarah ke biota laut yang diketahui dapat menghasilkan senyawa aktif (Ismet, 2007).

Salah satu biota laut yang berpotensi untuk menjadi bahan baku obat ialah Alga. Alga secara luas digunakan sebagai bahan makanan, bahan bagi industri kosmetika dan juga digunakan untuk pengobatan berbagai penyakit. Pemanfaatan alga untuk pengobatan disebabkan karena alga kaya akan senyawa bioaktif yang dapat digunakan untuk pengobatan berbagai penyakit (Basir et al, 2017).

Penelitian telah banyak dilakukan untuk mengkaji senyawa bioaktif berbagai jenis alga, salah satunya alga hijau yang memiliki aktivitas antimikroba (Mishra et al, 2016). Hal ini disebabkan karena di dalam alga hijau terdapat komponen bioaktif yang terdiri dari fenol, alkaloid dan terpen yang memiliki aktivitas antimikroba dan antioksidan (Perez et al, 2016). Salah satu alga hijau yang memiliki potensi antimikroba ialah alga dengan genus Halimeda dengan jenis Halimeda opuntia.

Halimeda opuntia sendiri sering ditemukan di daerah tropis (Basir et al, 2017) dimana Selat Lembeh Bitung berada dalam kawasan tersebut. Melihat komponen bioaktifnya serta lokasi penyebarannya maka peneliti tertarik untuk melakukan penelitian aktivitas antimikroba dari alga Halimeda opuntia yang terdapat di Selat Lembeh Bitung.

\section{METODE PENELITIAN}

\section{Alat dan Bahan}

Alat yang digunakan dalam penelitian ini yaitu masker, sarung tangan, gunting, pisau, tabung oksigen, snorkel, fins, zipper lock bag, botol $600 \mathrm{ml}$, talenan, cool box, kamera underwater, erlenmeyer (Pyrex), corong, oven, timbangan analitik, spatula, corong pisah, gelas ukur, gelas kimia (Pyrex), cawan petri, autoklaf, pinset, pembakar spritus, vortex mixer, micro tubes, batang pengaduk, Laminar air flow, rak tabung reaksi, tabung reaksi, lemari pendingin, inkubator, cakram (paper disc), mikropipet, digital caliper, kertas label, spidol permanen. Bahan-bahan yang digunakan yaitu alga Halimeda opuntia, mikroba uji Staphylococcus aureus, Escherichia coli, Candida albicans, etanol, akuades, n-heksan, kloroform, metanol, pepton, beef extract, natrium klorida, agar, kloramfenikol paper disc, tissue, aluminium foil, plastic wrap, kertas saring, es batu.

\section{Pengambilan Sampel}

Sampel alga Halimeda opuntia diambil dari Selat Lembeh Bitung menggunakan alat bantu (masker, snorkel, fins dan tabung oksigen). Sampel yang diperoleh dimasukkan ke dalam zipper lock bag dan diletakkan didalam cool box, kemudian langsung dibawa ke Laboratorium Farmakognosi dan Fitokimia Program Studi Farmasi Universitas Sam Ratulangi. Sampel 
difoto dan diberi label serta nomor sampel, untuk selanjutnya dideterminasi.

\section{Ekstraksi Sampel}

Ekstrak alga Halimeda opuntia sebanyak 140,0 g diekstraksi dengan cara maserasi. Sampel dibersihkan dan dipotong kecil-kecil dimasukkan ke dalam botol 600 ml, kemudian direndam dengan pelarut etanol sampai sampel terendam semuanya dan dibiarkan selama 24 jam. Sampel yang direndam kemudian disaring menggunakan kertas saring menghasilkan filtrat 1 dan debris 1. Debris 1 kemudian diremaserasi dengan pelarut etanol sampai terendam semuanya dan dibiarkan selama 24 jam, sampel tersebut disaring menggunakan kertas saring menghasilkan filtrat 2 dan debris 2. Debris 2 kemudian diremaserasi dengan pelarut etanol sampai terendam semuanya dan dibiarkan selama 24 jam, sampel tersebut disaring menggunakan kertas saring menghasilkan filtrat 3 dan debris 3. Filtrat 1, 2, dan 3 dicampur menjadi satu kemudian disaring, lalu dikeringkan menggunakan oven dengan suhu $40^{\circ} \mathrm{C}$ dan selanjutnya ditimbang menggunakan timbangan analitik, diperoleh ekstrak etanol sampel sebanyak 0,42 g. Selanjutnya ekstrak kasar alga Halimeda opuntia digunakan dalam fraksinasi dan pengujian antimikroba.

\section{Fraksinasi Sampel}

Sebanyak 0,25 g ekstrak kasar alga Halimeda opuntia dimasukkan ke dalam gelas kimia, kemudian dilarutkan dengan metanol $80 \%$ sebanyak $100 \mathrm{~mL}$. Setelah larut, dimasukan kedalam corong pisah dan ditambahkan pelarut n-heksan sebanyak 100
$\mathrm{mL}$ setelah itu dikocok dalam corong pisah sampai homogen. Dibiarkan sampai terbentuk lapisan metanol dan lapisan nheksan, kemudian masing-masing lapisan ditampung dalam erlenmeyer yang berbeda. Lapisan n-heksan kemudian dikeringkan menggunakan oven dengan suhu $40^{\circ} \mathrm{C}$, lalu ditimbang dan diperoleh fraksi n-heksan sebanyak 0,90 g. Selanjutnya, lapisan metanol ditambahkan akuades sebanyak 100 $\mathrm{mL}$ kemudian dipartisi dengan pelarut kloroform dengan perbandingan 1:1 v/v dalam corong pisah, setelah itu dikocok kembali sampai homogen. Dibiarkan sampai tebentuk dua lapisan yaitu lapisan metanol dan kloroform, kemudian masing-masing lapisan ditampung dalam erlenmeyer yang berbeda. Lapisan kloroform selanjutnya dikeringkan menggunakan oven dengan suhu $40^{\circ} \mathrm{C}$, lalu ditimbang berat sampel dan diperoleh fraksi kloroform sebanyak 1,20 g. Lapisan metanol kemudian dikeringkan menggunakan oven dengan suhu $40^{\circ} \mathrm{C}$, lalu ditimbang dan diperoleh fraksi metanol sebanyak 1,70 g. Ketiga fraksi yang diperoleh akan digunakan dalam pengujian antimikroba.

\section{Sterilisasi Alat}

Alat-alat yang digunakan dalam penelitian aktivitas antimikroba ini disterilkan terlebih dahulu. Alat-alat gelas disterilkan dengan autoklaf pada suhu $121^{\circ} \mathrm{C}$ selama 15 menit, pinset dibakar dengan pembakaran diatas api langsung dan media disterilkan diautoklaf pada suhu $121^{\circ} \mathrm{C}$ selama 15 menit (Mpila, 2012). 


\section{Pembuatan Media Cair B1}

Pepton $0,5 \mathrm{~g}$, beef extract $0,3 \mathrm{~g}$, natrium klorida 0,3 g dan akuades sebanyak $100 \mathrm{ml}$ diaduk sampai homogen kemudian disterilkan dalam autoklaf pada suhu $121^{\circ} \mathrm{C}$ selama 15 menit dan setelah itu didinginkan. Setelah dingin, media cair B1 di tutup dengan aluminium foil (Dwijendra et al, 2014).

\section{Kultur Mikroba}

Mikroba yang digunakan yaitu bakteri Escherichia coli dan Staphylococcus aureus dan jamur Candida albicans. Masingmasing mikroba diambil dari biakan murni menggunakan mikropipet sebanyak $100 \mu \mathrm{L}$ dan dimasukkan ke dalam masing-masing tabung reaksi yang sudah berisi media cair B1 sebanyak $1 \mathrm{ml}$ dan kemudian ditutup menggunakan aluminium foil. Setelah itu, diinkubasi dalam inkubator pada suhu $37^{\circ} \mathrm{C}$ selama 1 x 24 Jam (Dwijendra et al, 2014).

\section{Pembuatan Media Uji}

Pepton $0,5 \mathrm{~g}$, beef extract $0,3 \mathrm{~g}$, natrium klorida 0,3 g, agar 1,5 g dan akuades sebanyak $100 \mathrm{ml}$ diaduk sampai homogen kemudian disterilkan di autoklaf pada suhu $121^{\circ} \mathrm{C}$ selama 15 menit (Dwijendra et al, 2014).

\section{Pembuatan Larutan Uji}

Larutan uji dibuat dengan cara $1 \mathrm{mg}$ ekstrak kasar alga Halimeda opuntia dilarutkan dalam $200 \mu \mathrm{L}$ metanol dan dikocok hingga homogen menggunakan vortex. Perlakuan yang sama dilakukan pada fraksi n-heksan, fraksi kloroform dan fraksi metanol (Ortez,2005).

\section{Pembuatan Kontrol Positif dan Kontrol Negatif}

Kontrol positif dalam pengujian aktivitas antimikroba ini menggunakan kloramfenikol paper disc. Kontrol negatif yang digunakan dalam penelitian ini yaitu menggunakan pelarut metanol, dengan cara membuat larutan stok metanol dengan mengambil sebanyak $200 \mu \mathrm{L}$ metanol kemudian di totolkan pada paper disc (Lalamentik, 2017).

\section{Pengujian Aktivitas Antimikroba}

Metode yang digunakan dalam penelitian ini yaitu metode difusi agar (disc diffusion Kirby and Bauer). Pada pengujian aktivitas antimikroba ini, cakram (paper disc) yang digunakan berukuran $6 \mathrm{~mm}$ dengan daya serap $50 \mu \mathrm{L}$ tiap cakram. Sebanyak $300 \mu \mathrm{L}$ mikroba yang telah dikultur, dipipet dan diinokulasi pada $30 \mathrm{ml}$ media agar lalu diaduk hingga homogen dan kemudian dituangkan ke dalam cawan petri dan tunggu sampai media agar mengeras. Kemudian, larutan uji yang telah disiapkan ditotolkan pada masing-masing cakram dengan menggunakan mikropipet. Setelah agar mengeras, kertas cakram yang telah ditotolkan sampel Halimeda opuntia, kontrol positif dan kontrol negatif diletakkan ke dalam cawan petri dengan menggunakan pinset. Selanjutnya, cawan petri diberi label dan diinkubasi dalam inkubator pada suhu $37^{0} \mathrm{C}$ selama 1 x $24 \mathrm{Jam}$ (Ortez,2005).

\section{Pengamatan dan Pengukuran Diameter Zona Hambat}

Pengamatan dilakukan setelah 24 jam masa inkubasi. Daerah pada sekitaran cakram menunjukkan kepekaan mikroba 
terhadap antibiotik atau bahan antimikroba yang digunakan sebagai bahan uji yang dinyatakan dengan diameter zona bening. Diameter zona bening diukur menggunakkan digital caliper. Kemudian zona bening yang telah diukur, dikategorikan berdasarkan pedoman Davis dan Stout (1971).

\section{HASIL DAN PEMBAHASAN}

\section{Ekstraksi}

Alga Halimeda opuntia yang telah diambil dari Selat Lembeh Bitung dipotong kecil-kecil, hal ini dilakukan karena semakin kecil luas permukaan sampel maka akan semakin memperluas permukaan yang akan berinteraksi dengan pelarut, sehingga senyawa yang dapat ditarik oleh pelarut pun akan semakin banyak (Sineke et al, 2016). Setelah itu dilakukan proses ekstraksi dengan menggunakan metode maserasi. Metode maserasi dipilih karena cara pengerjaan dan peralatan yang digunakan sederhana serta mudah untuk dilakukan dan cocok untuk mengekstrak komponenkomponen yang tidak tahan akan suhu tinggi (Kristiani, 2014).

Maserasi sampel dilakukan dengan menggunakan pelarut etanol $96 \%$ karena pelarut ini memiliki kemampuan menyari dengan tingkat polaritas yang lebar mulai dari senyawa non polar sampai dengan senyawa polar (Saifudin et al, 2011). Ekstraksi dilakukan selama 3x24 jam dan setiap 24 jam ekstrak disaring dan dimaserasi kembali dengan pelarut yang baru hal ini disebut dengan remaserasi. Remaserasi dilakukan agar senyawa aktif dalam sampel dapat ditarik secara optimum (Huliselan et al, 2015). Massa ekstrak beserta rendemen yang dihasilkan dalam proses ekstraksi ditunjukkan pada Tabel 1.

Tabel 1. Rendemen ekstrak alga Halimeda opuntia

\begin{tabular}{ccccc}
\hline No. & Sampel & $\begin{array}{c}\text { Massa } \\
\text { Ekstrak } \\
(\mathbf{g})\end{array}$ & $\begin{array}{c}\text { Rendemen } \\
(\boldsymbol{\%})\end{array}$ & $\begin{array}{c}\text { Warna } \\
\text { Sampel }\end{array}$ \\
\hline 1. & $\begin{array}{c}\text { Ektsrak } \\
\text { Etanol }\end{array}$ & 0,42 & 0,3 & $\begin{array}{c}\text { Hijau } \\
\text { Pekat }\end{array}$ \\
\hline
\end{tabular}

\section{Fraksinasi}

Metode fraksinasi yang digunakan dalam penelitian ini yaitu metode partisi cair-cair yang merupakan metode pemisahan dengan menggunakan dua cairan pelarut yang tidak saling bercampur sehingga senyawa yang memiliki sifat non polar akan larut dalam pelarut non polar, yang semi polar akan larut dalam pelarut semi polar, dan yang bersifat polar akan larut ke dalam pelarut polar (Harborne, 1998).

Pelarut yang digunakan untuk proses fraksinasi ini yaitu n-heksan, kloroform dan metanol. Proses fraksinasi dilakukan secara bertingkat berdasarkan tingkat kepolaran pelarut yaitu mulai dari pelarut non polar selanjutnya semi polar dan terakhir pelarut polar (Harborne, 1998). Massa fraksi beserta rendemen yang dihasilkan dalam proses fraksinasi ditunjukkan pada Tabel 2.

Tabel 2. Rendemen fraksi alga Halimeda opuntia

\begin{tabular}{|c|c|c|c|c|}
\hline No. & Sampel & $\begin{array}{c}\text { Massa } \\
\text { Ekstrak } \\
\text { (g) }\end{array}$ & $\begin{array}{c}\text { Rendemen } \\
(\%)\end{array}$ & $\begin{array}{l}\text { Warna } \\
\text { Sampel }\end{array}$ \\
\hline 1. & $\begin{array}{l}\text { Fraksi } \\
\text { Heksan }\end{array}$ & 0,009 & 3,6 & $\begin{array}{l}\text { Hijau } \\
\text { Muda }\end{array}$ \\
\hline 2. & $\begin{array}{c}\text { Fraksi } \\
\text { Kloroform }\end{array}$ & 0,012 & 4,8 & $\begin{array}{l}\text { Coklat } \\
\text { muda }\end{array}$ \\
\hline 3. & $\begin{array}{c}\text { Fraksi } \\
\text { Metanol }\end{array}$ & 0,030 & 12,0 & $\begin{array}{c}\text { Coklat } \\
\text { tua }\end{array}$ \\
\hline
\end{tabular}


yang digunakan. Dimana, pelarut yang berbeda akan melarutkan senyawa-senyawa yang berbeda, sehingga jumlah fraksi yang dihasilkan pun juga berbeda (Mujipradhana et al, 2018).

\section{Uji Aktivitas Antimikroba}

Pengujian aktivitas antimikroba dilakukan dengan menggunakan metode difusi agar. Metode ini dipilih karena dapat digunakan untuk melihat sensitivitas berbagai jenis mikroba terhadap antimikroba pada konsentrasi tertentu (Akhyar, 2010).

Pada pengujian ini, daya antimikroba ditandai dengan adanya zona bening disekeliling cakram yang berukuran $6 \mathrm{~mm}$, hal ini menunjukkan adanya kepekaan mikroba terhadap ekstrak dan fraksi alga Halimeda opuntia. Konsentrasi ekstrak dan fraksi yang digunakan yaitu $250 \mu \mathrm{g}$ pada setiap paper disc yang memiliki daya serap $50 \mu \mathrm{L}$. Pengamatan dilakukan setelah diinkubasi pada suhu $37^{\circ} \mathrm{C}$ selama $1 \times 24$ jam dengan pengulangan sebanyak 3 kali pada masing-masing mikroba, pengulangan dilakukan dengan tujuan untuk lebih mengakuratkan hasil yang diperoleh.

Hasil pengukuran rata-rata diameter daya antimikroba dari ekstrak etanol, fraksi kloroform, fraksi metanol dan fraksi nheksan ditunjukkan pada Tabel 3.

Tabel 3. Hasil Pengukuran Rata-Rata Diameter Daya Antimikroba dari Ekstrak dan Fraksi Alga Halimeda opuntia

\begin{tabular}{ccccccc}
\hline & \multicolumn{7}{c}{ Rata- Rata Diameter $(\mathbf{m m})$} \\
\cline { 2 - 8 } Mikroba & EE & FK & FM & FH & + & - \\
\hline $\mathrm{Ec}$ & 6,20 & 0,00 & 0,00 & 0,00 & 20,15 & 0,00 \\
\hline $\mathrm{Sa}$ & 6,40 & 7,53 & 7,10 & 0,00 & 17,42 & 0,00 \\
\hline $\mathrm{Ca}$ & 0,00 & 0,00 & 0,00 & 0,00 & 12,45 & 0,00 \\
\hline
\end{tabular}

Keterangan :

Ec : Escherichia coli

$\mathrm{Sa} \quad$ : Staphylococcus aureus

$\mathrm{Ca} \quad$ : Candida albicans

EE : Ekstrak Etanol

FK : Fraksi Kloroform
FM : Fraksi Metanol

FH : Fraksi Heksan

$+\quad$ : Kontrol Positif

- $\quad$ : Kontrol Negatif
Dalam pengujian ini digunakan kontrol positif dan kontrol negatif sebagai pembanding. Kontrol positif yang digunakan dalam penelitian ini yaitu kloramfenikol, hal ini dikarenakan kloramfenikol memiliki spektrum kerja yang luas (Rahmawati, 2015).
Kontrol negatif berfungsi untuk mengetahui ada tidaknya pengaruh pelarut terhadap pertumbuhan mikroba uji. Kontrol negatif yang digunakan adalah metanol, karena pelarut yang digunakan untuk melarutkan larutan uji adalah metanol. Dari hasil yang diperoleh kontrol negatif tidak memiliki daya hambat antimikroba pada 
bakeri Escherichia coli dan Staphylococcus aureus dan jamur Candida albicans. Sehingga dapat diketahui, bahwa aktivitas yang ditunjukkan oleh ekstrak dan fraksi sampel alga Halimeda opuntia adalah murni dari senyawa aktif yang terkandung dalam sampel.

Pada pengujian aktivitas antimikroba dari sampel alga Halimeda opuntia penggolongan kekuatan daya antimikroba digolongkan menurut pedoman Davis and Stout (1971).

Pada ekstrak etanol, berdasarkan hasil yang diperoleh, menunjukkan bahwa diameter zona bening yang terbentuk pada Staphylococcus aureus dikategorikan sedang (6,40 $\mathrm{mm}$ ) dan pada Escherichia coli juga dikategorikan sedang $(6,20 \mathrm{~mm})$ sedangkan pada Candida albicans tidak menunjukkan adanya aktivitas. Hal ini menunjukkan bahwa ekstrak etanol memiliki senyawa aktif yang hanya dapat menghambat pertumbuhan bakteri Escherichia coli serta Staphylococcus aureus dan tidak memiliki aktivitas untuk menghambat pertumbuhan jamur Candida albicans, namun untuk aktivitas antibakteri, ekstrak etanol memiliki spektrum kerja yang luas karena dapat menghambat pertumbuhan bakteri baik Gram positif maupun Gram negatif.

Pada fraksi kloroform, berdasarkan hasil yang diperoleh, menunjukkan bahwa diameter zona bening yang terbentuk pada bakeri Staphylococcus aureus memiliki kekuatan antimikroba yang sedang (7,53 $\mathrm{mm}$ ) namun tidak menunjukkan adanya aktivitas antimikroba pada bakteri Escherichia coli dan jamur Candida albicans. Hal ini menunjukkan bahwa fraksi kloroform memiliki senyawa aktif yang hanya dapat menghambat pertumbuhan bakteri Staphylococcus aureus saja dan memiliki spektrum kerja yang sempit karena hanya dapat menghambat pertumbuhan bakteri Gram positif dan tidak memiliki aktivitas untuk menghambat bakteri Gram negatif dan jamur.

Pada fraksi metanol, berdasarkan hasil yang diperoleh, menunjukkan bahwa diameter zona bening yang terbentuk pada bakteri Staphylococcus aureus memiliki kekuatan antimikroba yang sedang $(7,10$ $\mathrm{mm}$ ) namun tidak menunjukkan adanya aktivitas antimikroba pada bakteri Escherichia coli dan jamur Candida albicans. Hal ini menunjukkan bahwa fraksi metanol memiliki senyawa aktif yang hanya dapat menghambat pertumbuhan bakteri Staphylococcus aureus saja dan memiliki spektrum kerja yang sempit karena hanya dapat menghambat pertumbuhan bakteri Gram positif dan tidak memiliki aktivitas untuk menghambat bakteri Gram negatif dan jamur.

Pada fraksi n-heksan, berdasarkan hasil yang diperoleh, tidak menunjukkan adanya aktivitas antimikroba pada mikroba uji Escherichia coli, Staphylococcus aureus dan Candida albicans. Ketidak-reaktifan fraksi n-heksan dalam menghambat pertumbuhan mikroba uji menunjukkan bahwa senyawa metobolit sekunder yang larut dalam nheksan tidak memiliki aktivitas antimikroba (Zakaria et al, 2017).

Dari hasil yang diperoleh menunjukkan bahwa ekstrak etanol hanya memiliki aktivitas untuk menghambat bakteri Escherichia coli dan Staphylococcus aureus, sedangkan fraksi kloroform dan fraksi metanol hanya memiliki aktivitas untuk 
menghambat bakteri Staphylococcus aureus saja dan untuk ekstrak dan semua fraksi alga Halimeda opuntia tidak memiliki aktivitas untuk menghambat jamur Candida albicans. Selain itu, Staphylococcus aureus lebih sensitif terhadap ekstrak dan fraksi sampel, hal ini disebabkan karena struktur dinding sel bakteri Gram positif lebih sederhana sehingga memudahkan senyawa antimikroba untuk masuk ke dalam sel dan menemukan sasaran untuk bekerja (Kumayas et al, 2015).

\section{KESIMPULAN}

Berdasarkan hasil penelitian yang telah dilakukan dapat disimpulkan bahwa ekstrak etanol dari sampel alga Halimeda opuntia yang diperoleh dari Selat Lembeh Bitung memiliki aktivitas untuk menghambat bakteri Escherichia coli dan Staphylococcus aureus dengan kategori daya hambat sedang, sedangkan untuk fraksi kloroform dan fraksi metanol hanya memiliki aktivitas untuk menghambat bakteri Staphylococcus aureus dengan kategori daya hambat sedang dan ekstrak serta semua fraksi tidak memiliki aktivitas untuk menghambat jamur Candida albicans.

\section{DAFTAR PUSTAKA}

Akhyar, 2010. Uji Daya Hambat dan Analisis KLT Bioautografi Ekstrak Akar dan Buah Bakau ( Rhizophora stylosa Griff.) Terhadap Vibrio Harveyi [skripsi]. Fakultas Farmasi Universitas Hasanuddin, Makassar.

Basir, A., et al. 2017. Aktivitas Antibakteri dan Antioksidan Alga Hijau Halimeda gracilis dari Kabupaten Kepulauan Seribu. Jurnal
Pengolahan Hasil Perikanan Indonesia. 20 : (2), 211-218.

Dwijendra, I. M., et al. 2014. Aktivitas Antibakteri dan Karakterisasi Senyawa Fraksi Spons Lamellodysidea herbacea yang diperoleh dari Teluk Manado. Pharmacon. 3: (4), 1-9.

Harborne, J.B. 1998. Phytochemical Methods: A Guide to Modern Techniques of Plant Analysis. Third Edition. UK : Chapman \& Hall.

Huliselan, Y. M., et al. 2015. Aktivitas Antioksidan Ekstrak Etanol, Etil Asetat dan N-Heksan dari Daun Sesewanua (Clerodendron squamatum Vahl.). Pharmacon. 4: (3), 155-163.

Ismet, M. S. 2007. Penapisan Senyawa Bioaktif Spons Aaptops dan Petrosia $s p$. dari Lokasi yang Berbeda [tesis]. Pasca sarjana, Institut Teknologi Bandung, Bandung.

Kristiani, V. 2014. Pengaruh Konsentrasi Etanol dan Waktu Maserasi Terhadap Perolehan Fenolik, Flavonoid, dan Aktivitas Antioksidan Ekstrak Rambut Jagung [skripsi]. Fakultas Teknik, Universitas Katolik Widya Mandala, Surabaya.

Kumayas, A. R., et al. 2015. Aktifitas Antibakteri dan Karateristik Gugus Fungsi dari Tunikata Polycarpa aurata. Pharmacon. 4: (1), 32-44.

Lalamentik, G. 2017. Aktivitas Antibakteri Ekstrak Karang Lunak Klyxum sp. yang Diperoleh dari Teluk Manado [skripsi]. Fakultas Matematika dan Ilmu Pengetahuan Alam, Universitas Sam Ratulangi, Manado. 
Mishra, J., et al. 2016. Antibacterial Activity Of Seaweed Halimeda opuntia from The Coasts of South Andaman. Global Journal of Bio-Science and Biotechnology. 5: (3), 345-348.

Mpila, D. A. 2012. Uji Aktivitas Antibakteri Ekstrak Etanol Daun Mayana (Coleus atropurpureus benth) Terhadap Staphylococcus aureus, Escherichia coli dan Pseudomas aeruginosa Secara Invitro [skripsi]. Fakultas Matematika dan Ilmu Pengetahuan Alam, Universitas Sam Ratulangi, Manado.

Mujipradhana, V. N., et al. 2018. Aktivitas Antimikroba dari Ekstrak Ascidian Herdmania momus pada Mikroba Patogen Manusia. Pharmacon. 7: (3), 338-347.

Ortez, J. H. 2005. Disk Diffusion testing in manual of antimicrobial susceptibility testing. Marie B. Coyle (Coord. Ed). American society for Microbiology.

Perez, M. J., et al. 2016. Antimicrobial Action of Compounds from Marine Seaweed-A Review. Marine Drugs. 14: (52), 1-38.

Rahmawati, M. 2015. Uji Aktivitas Antimikroba Ekstrak Etanol dan Air Rimpang Pacing ( Costus spiralis) Terhadap Bakteri Escherichia coli, Shigella dysenteriae, Salmonella typhimurium, Bacillus subtilis, Staphylococcus aureus Serta Fungi Candida albicans [skripsi]. Fakultas Kedokteran dan Ilmu Kesehatan, Universitas Islam Negeri Syarif Hidayatullah, Jakarta.

Saifudin, A., et al. Teruna. 2011. Standarisasi Bahan Obat Alam. Yogyakarta: Graha Ilmu.
Sineke, F. U., et al. 2016. Penentuan Kandungan Fenolik dan Sun Protection Factor (SPF) dari Ekstrak Etanol dari Beberapa Tongkol Jagung (Zea mays L.). Pharmacon. 5: (1), 275-283.

Zakaria., et al. 2017. Aktivitas Antibakteri dari Fraksi Artocarpus Integer (Thunb.) Merr. dengan Metode Difusi Agar. Jurnal Industri Hasil Perkebunan. 12: (2), 1-6 